\title{
PERAN GURU SEBAGAI PENGAJAR DALAM PENGEMBANGAN INOVASI PENDIDIKAN DI ERA 4.0
}

\author{
Khalillul Rahman \\ Email: 181011121006@ulm.ac.id \\ Program StudiPendidikanSejarahFakultasKeguruandanIlmuPendidikan \\ UniversitasLambungMangkurat \\ Banjarmasin
}

\begin{abstract}
Abstrak
Inovasi pendidikan merupakan suatu perubahan yang baru, dan kualitatif berbeda dari hal yang ada sebelumnya, serta sengaja diusahakan untuk meningkatkan kemampuan guna mencapai tujuan tertentu dalam pendidikan. Tujuan penelitian ini untuk mendeskripsikan bentuk dari inovasi yang dilakukan dalam dunia pendidikan dengan memanfaatkan teknologi terutama di era revolusi industri 4.0. Metode penelitian yang digunakan adalah metode kualitatif. Hasil dari penelitian yang dilakukan diketahui bahwa terdapat banyak model dalam pelaksanaan inovasi pendidikan diantaranya ada konsepsi perubahan, pengusulan perubahan, adopsi dan implementasi. Tahapan dalam proses inovasi pendidikan diawali dengan inisiasi perubahan, terdapat agenda (setting), penyesuaian (matching), redefinisi atau re-strukturisasi, klarifikasi dan rutinisasi. Bentuk inovasi yang telah dilakukan dalam pendidikan di Indonesia telah banyak dimulai dengan proyek perintis sekolah pembangunan, kurikulum 1975, proyek pamong, SMP terbuka, universitas terbuka, pembaruan sistem pendidikan kependidikan, kurikulum 1984, kurikulum 1994, kurikulum KBK, kurikulum KTSP, kurikulum 2013. Saat ini dengan berkembangnya teknologi informasi serta digaungkannya era revolusi industri 4.0 maka inovasi pendidikan juga perlu dilakukan. Bentuk dari inovasi yang dilakukan dalam rangka pengoptimalan pendidikan guna menyongsong era revolusi industri adalah dengan dibentuknya pembelajaran digital sebagaimana saat ini dikenal dengan istilah Sistem Pembelajaran Dalam Jaringan (SPADA).
\end{abstract}

\section{PENDAHULUAN}

Istilah "inovasi" merupakan kata yang menarik dalam manajemenpada tiga dasawarsa belakangan. Para pimpinan bisnis dan politisi dalam memenangkan persaingan selalu menggunakan istilah inovasi atau perubahan radikal sebagai jargon kompetisi dan perjuang bisnis dalam kiprahnya 
Drucker (1990:1 dan 11) berpendapat bahwa inovasi adalah sebagai perubahan yang menciptakan dimensi baru kinerja".Sesungguhnya harus diakui bahwa manusia memiliki kemampuan untuk beradaptasi dan menciptakan sesuatu untuk pembaharuan". Selanjutnyamenurut Rogers dan Shoemaker (1987:26) inovasi adalah gagasan,tindakan atau barang yang dianggap baru oleh seseorang. Tidak menjadi soal, sejauh dihubungkan dengan tingkah laku manusia, apakah ide itu betul-betul baru atau tidak jika diukur dengan selang waktu sejak digunakan nya atau ditemukan nya pertama kali.

Dalam konteks lain inovasi adalah pengenalan cara-cara baruatau kombinasi baru dari cara-cara lama dalam mentrasformasikan input menjadi output sehingga menghasilkan perubahan besar dalamperbandingan antara nilai guna dan harga yang ditawarkan kepadakonsumen dan atau pengguna (Fontana, 2009: 22). Dari beberapa pendapat di atas, jelaslah bahwa inovasi adalahmemperkenalkan ide baru atau barang baru, pelayanan baru dancara-cara baru yang lebih bermanfaat bagi kehidupan manusia. Dalamkonteks ini tentu saja inovasi biasanya berhubungan dengan kreativitasmanusia. Bahkan hakikat inovasi atau innovation berasal dari katato innovate yang mempunyai arti yaitu membuat perubahan atau mem-perkenalkan sesuatu yang baru.

Inovasi pendidikan sendiri berati perubahan hal hal dalam strategi pendidikan yang dapat di simpulkan bahwa berkembang nya sistem atau tatanan cara yang pembelajaran yang modern dengan cara yang baru seiring perkembangan nya zaman itu sendiri.

\section{PERAN GURU SEBAGAI SEBUAH PROFESI}

Karena Guru sebagai sebuah sarana dalam tolak ukur pembelajaran harus memberikan hal positif sebagai contoh yang bagus terutama dari sikap, attitude dan arti menghargai terhadap sesama murid atau pun terhadap seorang guru tersebut. Guru sebagai tenaga pendidik yang dipandang memiliki keahlian tertentu dalam pendidikan dan pembelajaran, diserahi tugas dan wewenang untuk mengelola kegiatan pembelajaran agar dapat mencapai tujuan tertentu yaitu terjadinya perubahan tingkah laku siswa dengan tujuan pendidikan nasional dan tujuan institusional yang telah dirumuskan. Menurut Danim (2002:15) guru memiliki multiperan yaitu sebagai pendidik, pengajar, dan pelatih. novasi yang dilakukan terhadap guru memberikan pengaruh terhadap pada peran dan fungsi guru dalam melaksanakan pendidikan dan pembelajaran. Secara khusus dalam pembelajaran guru mempunyai peran dan fungsi untuk mendorong, membimbing dan memfasilitas siswa untuk belajar.

Ki Hajar Dewantara menegaskan pentingnya peran dan fungsi dalam pendidikan dengan ungkapan: Ing ngarsa sung tulada berarti guru berada di depan memberi teladan, ing madya mangun karsa, berarti guru berada ditengah menciptakan peluang untuk berprakarsa, dan tut wuri handayani berarti guru dari belakang memberikan dorongan dan arahan.

Mencermati peran dan fungsi guru yang dikemukakan oleh Ki Hajar Dewantara tersebut maka sesungguhnya peran guru itu sungguhlah luas. Keluasan peran guru tersebut 
dipaparkan Adams dan Dickey sebagaimana dikutip Hamalik (2004:123) yaitu peran guru sesungguhnya sangat luas yang meliputi empat hal besar yaitu:

1. Guru sebagai pengajar (teacher as instructor).

Guru bertugas memberikan pengajaran di dalam sekolah (kelas) yaitu menyampaikan pelajaran agar peserta didik memahami dengan baik semua pengetahuan yang telah disampaikan itu

2. Guru sebagai pembimbing (teacher as counsellor). Guru berkewajiban memberikan bantuan kepada peserta didik agar mampu menemukan masalahnya sendiri, memecahkan masalahnya sendiri, mengenal dirinya sendiri dan menyesuaikan diri dengan lingkungannya.

3. Guru sebagai ilmuwan (teacher as scientist). Guru dipandang sebagai orang yang paling berpengetahuan. Guru bukan saja berkewajiban untuk menyampaikan pengetahuan yang dimilikinya kepada peserta didik, tetapi juga berkewajiban mengembangkan pengetahuan dan terus menerus memupuk pengetahuan yang telah dimilikinya.

4. Guru sebagai sebagai pribadi (teacher as person). Sebagai pribadi setiap guru harus memiliki sifat-sifat yang disenangi oleh peserta didiknya, oleh orang tua dan masyarakat.

Inovasi yang dilakukan terhadap guru memberikan pengaruh terhadap pada peran dan fungsi guru dalam melaksanakan pendidikan dan pembelajaran. Secara khusus dalam pembelajaran guru mempunyai peran dan fungsi untuk mendorong, membimbing dan memfasilitas siswa untuk belajar.

Karena adanya inovasi dari seorang guru dalam melaksanakan pembelajaran. Dalam hal ini Goble sebagaimana dikutip Mudlofir (2014:31) mengidentifikasi beberapa kecenderungan perubahan peranan guru sebagai berikut:

1. Kecenderungan ke arah diversifikasi fungsi-fungsi proses pembelajaran dan peningkatan tanggung jawab yang lebih besar dalam pengorganisasian isi dari proses pembelajaran.

2. Kecenderungan ke arah bergesernya titik berat dari pengajaran yang merupakan pengalihan/transformasi pengetahuan oleh guru kepada proses belajar oleh siswa, dengan memanfaatkan semaksimal mungkin penggunaan sumber-sumber belajar yang inovatif di lingkungan masyarakat.

3. Kecenderungan ke arah individualisasi proses belajar dan berubahnya struktur hubungan antara guru dan siswa.

4. Kecenderungan ke arah penggunaan teknologi pendidikan modern dan penguasaan atas pengetahuan dan ketrampilan yang diperlukan.

5. Kecenderungan kearah diterimanya bentuk kerja sama yang ruang lingkupnya lebih luas bersama guru-guru yang mengajar di sekolah lain, dan berubahnyaa struktur hubungan antara para guru sendiri. 


\section{GURU INDONESIA DAN TANTANGAN PROFESIONALISME}

Inovasi dan modernisasi keduanya merupakan perubahan sosial, perbedaannya pada penekanan ciri dari perubahan itu. Inovasi menekankan pada ciri adanya sesuatu yang diamati sebagai sesuatu yang baru bagi individu atau masyarakat, sedangkan modernisasi menekankan pada adanya proses perubahan dari tradisional ke modern atau dari yang belum maju ke arah yang lebih maju. Jadi dapat disimpulkan bahwa diterimanya suatu inovasi sebagai tanda adanya modernisasi. Untuk membentuk keluarga kecil bahagia dan sejahtera perlu dilaksanakan program Keluarga Berencana (KB). Program tersebut merupakan hal baru bagi masyarakat maka programKB adalah suatu inovasi masyarakat yang sudah mau menerima ide program KB dan melaksanakannya berarti telah memenuji ciri masyarakat modern yaitu siap menghadapai perubahan dan meninggalkan pola pikir tradisional "banyak anak banyak rejeki".

Adanya inovasi dan modernisasi tidak terlepas dari adanya teknologi. Teknologi sering kali diartikan sebagai peralatan yang serba elektronik, seperti mesin komputer. Namun sebenarnya teknologi juga merupakan aplikasi ilmu pengetahuan yang sistematis (Salisbury, 1996:7). Dalam uraian berikut ini dapat disimak beberapa pendapat para ahli tentang teknologi: Simon yang dikutip oleh Salisbury mengemukakan, teknologi sebagai disiplin rasional yang dirancang untuk meyakinkan manusia akan keahliannya menghadapi alam fisik atau lingkungan melalui penerapan hukum atau aturan ilmiah yang telah ditentukan (Salisbury, 1996:7).

Seattler mengutip asal katanya - techne (bahasa Yunani), sedang makna seni, kerajinan tangan atau keahlian. Kemudian, Seattler menerangkan bahwa teknologi bagi bangsa Yunani kuno diakui sebagai suatu kegiatan khusus, dan sebagai suatu pengetahuan (Salisburry, 1996: 7). Dari pendapat para ahli di atas, dapat disimpulkan bahwa teknologi: 1) Dapat diterjemahkan sebagai teknik atau cara pelaksanaan suatu kegiatan atau sebagai suatu proses;

2) Mengacu pada penggunaan mesin dan perangkat keras; Terkait dengan sifat rasional dan ilmiah;

3) Menunjuk suatu keahlian, baik itu seni atau kerajinan tangan dan merupakanaplikasi dan ilmu pengetahuan

Tegasnya inovasi adalah proses pembaharuan dalam berbagai aspek kehidupan yang menciptakan hal-hal baru dan berbeda dengan keadaan dan bentuk sebelumnya dalam mencapai kemajuan, kesejahteraan dan kebaikan bersama manusia sebagai formulasi kebudayaannya.

\section{SIMPULAN}

Inovasi pendidikan di Indonesia, masih terfokus pada kurikulum yang berubah-ubah hal ini dipengaruhi oleh keadaan politik dan ekonomi. Sehingga, kerancuan penataan pendidikan 
akan selalu ada dan selalu terpicu. Kondisi pendidikan yang seperti itu, dapat memicu inovasi yang cukup banyak dan berkembang. Inovasi itu bahkan membuat pendidik akan sulit untuk, melaksanakanya kepada peserta didik. Maka, diperlukan sebuah ketegasan dan pembatasan dalam inovasi pendidikan. Sehingga, mampu memberikan dampak yang cukup baik bagi pendidikan, dengan cara mungkin guru harus dituntut bisa dalam segala hal aspek teknologi seiring berkembang zaman. Karena guru wajib berinvoasi di setiap pelaksanaan pembelajaran dengan penggunaan media yang kekinian mampu membuat pembelajaran yang efektif dan mudah di pahami.

\section{REFERENSI}

Anis, M. Z. A., Putro, H. P. N., Susanto, H., \&Hastuti, K. P. (2020). Historical Thinking Model in Achieving Cognitive Dimension of Indonesian History Learning.PalArch's Journal of Archaeology of Egypt/Egyptology, 17(7), 7894-7906.

Anis, M. Z. A., Susanto, H., \&Mardiani, F. (2021, February). Analysis of the Effectiveness of MPBH: The Mains of Mandai as a Saving Food in Banjarmasin Community. In The 2nd International Conference on Social Sciences Education (ICSSE 2020) (pp. 89-94).Atlantis Press.

Efendi, I., Prawitasari, M., \& Susanto, H. (2021).ImplementasiPenilaianPembelajaranPadaKurikulum 2013 Mata PelajaranSejarah.Prabayaksa: Journal of History Education, 1(1), 21-25.

Susanto, H. (2020). ProfesiKeguruan. Banjarmasin: FKIP UniversitasLambungMangkurat.

Susanto, H., \&Akmal, H. (2018).EfektivitasPenggunaanAplikasiPembelajaranBerbasis Mobile Smartphone Sebagai Media PengenalanSejarahLokalMasaRevolusiFisik Di Kalimantan Selatan PadaSiswaSekolahMenengahAtas.HISTORIA: Jurnal Program StudiPendidikanSejarah, 6(2), 197-206.

Susanto, H., Irmawati, I., Akmal, H., \& Abbas, E. W. (2021).Media Film DokumenterMasuknya Islam Ke Nusantara danPengaruhnyaTerhadapKeterampilanBerpikirKritisSiswa.HISTORIA: Jurnal Program StudiPendidikanSejarah, 9(1).

Danim, Sudarwan, Inovasi Pendidikan, Bandung: Pustaka Setia, 2002.

Drucker, Feter. F Foundations, Leading For Innovation, New York:1990.

Fontana, Avanti, Innovate We Can!, Jakarta: PT. Gramedia, 2009 
Mudlofir, A. (2014). Pendidik Profesional. Konsep, Strategi dan Aplikasinya Dalam Peningkatan Mutu Pendidikan di Indonesia. Jakarta: Rajagrafindo Persada.

Hamalik, O. (2004). Proses Belajar Mengajar. Jakarta: Bumi Aksara.

Mulyasa, E. (2004). Kurikulum Berbasis Kompetensi, Konsep, Karakteristik dan Implementasi. Bandung: Remaja Rosdakarya. 